\title{
New species of Cyphocharax (Characiformes: Curimatidae) from the upper rio Negro, Amazon basin
}

\author{
Bruno F. Melo ${ }^{1}$ and Richard P. Vari²
}

A new species of Cyphocharax, Curimatidae, apparently endemic to the blackwater upper rio Negro of the Amazon basin in northern Brazil, is described. The new species is readily distinguished from its congeners by the presence of a distinctly longitudinally elongate, posteriorly vertically expanding patch of dark pigmentation along the midlateral surface of the caudal peduncle, with the patch extending from the base of the middle caudal-fin rays anteriorly past the vertical through the posterior terminus of the adipose fin. The new species additionally differs from all congeners in details of body and fin pigmentation and meristic and morphometric ratios. Evidence for the assignment of the species to Cyphocharax and the occurrence of other species of the Curimatidae apparently endemic to the upper rio Negro catchment is discussed.

Uma espécie nova de Cyphocharax, Curimatidae, aparentemente endêmica das águas escuras do rio Negro, bacia amazônica no norte do Brasil, é descrita. A espécie nova é prontamente distinguida de suas congêneres pela presença de uma mancha escura distintamente alongada longitudinalmente e posteriormente expandida na vertical ao longo da superfície lateral do pedúnculo caudal, sendo estendida da base dos raios medianos da nadadeira caudal até a linha vertical do término da nadadeira adiposa. Adicionalmente, a espécie nova difere de todas as congêneres nos detalhes do corpo, pigmentação das nadadeiras e nas proporções merísticas e morfométricas. As evidências para alocação da espécie no gênero Cyphocharax e a ocorrência de outras espécies de Curimatidae aparentemente endêmicas do alto rio Negro são discutidas.

Key words: Biodiversity, Blackwater, Neotropical fish, Pigmentation, Taxonomy.

\section{Introduction}

The genus Cyphocharax Fowler, 1906, is widely distributed throughout South American freshwaters and has the greatest geographic range of any genus in the family Curimatidae. At the northern limit of the range of the genus, the trans-Andean species C. magdalenae extends from the Pacific versant rivers of Costa Rica (Vari, 1992a) south into western Colombia (Maldonado-Ocampo et al., 2010). At the other extreme of the range of the genus, $C$. voga and $C$. saladensis inhabit estuarine rivers of the lower portions of río de La Plata basin in Argentina (Vari, 1992a). Intervening regions of South America are home to numerous species of Cyphocharax whose known distributions range from a single locality to broad regions of the continent. With 37 valid species, Cyphocharax is by far the most speciose among the eight genera in the Curimatidae (Vari, 2003; Vari et al., 2012). Of the species in Cyphocharax, over half (20 spp.) occur in the Amazon basin (Vari, 1992a) making that catchment the epicenter for the genus in terms of species richness.
Notwithstanding the description of numerous species of the Curimatidae as new in the last quarter century, ichthyological explorations across the range of the family continue to regularly reveal previously unknown species of the family (Vari \& Blackledge, 1996; Pavanelli \& Britski, 1999; Vari \& Chang, 2006; Lucinda \& Vari, 2009; Netto-Ferreira \& Vari, 2011; Vari et al., 2010, 2012; Wosiacki \& Miranda, 2013). A recent expedition to the region of São Gabriel da Cachoeira in the blackwater upper rio Negro of northern Amazonian Brazil yielded a previously unknown species of Cyphocharax with a distinctive pigmentation pattern on the caudal peduncle. We herein describe that species as new.

\section{Material and Methods}

Counts and measurements follow Vari (1992a). Measurements were point-to-point linear distances taken using digital caliper with a precision of $0.1 \mathrm{~mm}$. In the description, the number of examined specimens with a particular count

${ }^{1}$ Laboratório de Biologia e Genética de Peixes, Departamento de Morfologia, Instituto de Biociências, Universidade Estadual Paulista, District Rubião Júnior s/n, 18618-970 Botucatu, SP, Brazil. melo@ibb.unesp.br

${ }^{2}$ Division of Fishes, Department of Vertebrate Zoology, MCR-159, National Museum of Natural History, PO Box 37012, Smithsonian Institution, 20013-7012 Washington DC, USA. varir@si.edu 
is indicated in parentheses and the value of the holotype is designated by an asterisk. Vertebrae were counted from radiographs. Comparisons were made to the subset of the species of Cyphocharax most similar to the new form and redescribed or described in Vari (1992a), Vari \& Blackledge (1996), Vari \& Chang (2006) and Vari et al. (2010, 2012). Abbreviations in the text are head length (HL) and standard length (SL). Collection abbreviations are: Laboratório de Biologia e Genética de Peixes da Universidade Estadual Paulista (LBP), Botucatu, SP; Laboratório de Ictiologia de Ribeirão Preto da Universidade de São Paulo (LIRP), Ribeirão Preto, SP, and Museu de Zoologia da Universidade de São Paulo (MZUSP), São Paulo, SP.

\section{Cyphocharax sanctigabrielis, new species Fig. 1}

Holotype. MZUSP 115004, 60.7 mm SL, Brazil, Amazonas, São Gabriel da Cachoeira, Igarapé Nouba Uba, near BR-307 road, upper rio Negro, Amazon basin, 0000.321’N 6655.357’W, 9 Aug 2008, C. Oliveira, M. I. Taylor, M. A. Alexandrou \& J. I. R. Porto.

Paratypes. LBP 6963, 6, 44.3-67.0 mm SL (tissues 33399 and 33400); collected with holotype.
Diagnosis. Cyphocharax sanctigabrielis is distinguished from all other species of Cyphocharax by the presence on the lateral surface of the caudal peduncle of a distinct, longitudinally elongate, posteriorly often vertically expanded, darkly pigmented mark extending anteriorly from the base of the median caudal-fin rays to the vertical through the posterior limit of the base of the adipose fin. Dark pigmentation on the caudal peduncle is absent in C. abramoides, C. aspilos, C. derhami, C. festivus, C. leucostictus, C. magdalenae, C. microcephalus, C. multilineatus, C. nigripinnis, C. notatus, $C$. pinnilepis, C. plumbeus, $C$. stilbolepis, and $C$. vexillapinnus. When present, the dark pigmentation in that region in other congeners can alternatively be rotund (C. gangamon, $C$. gillii, C. gouldingi, C. helleri, C. mestomyllon, C. oenas, C. punctatus, C. spiluropsis, and C. vanderi), somewhat triangular with its posterior border darker (C. meniscaprorus), a vertically oriented ellipsoid (C. aninha), in the form of an elongate stripe (C. laticlavius, C. modestus, C. nagelii, and C. pantostictus) or longitudinally ovoid but terminating anteriorly distinctly posterior to the vertical through the posterior limit of the base of the adipose fin (C. biocellatus, C. gilbert, $C$. saladensis, C. santacatarinae, C. signatus, C. spilotus, C. spilurus, and C. voga). Cyphocharax sanctigabrielis can be further diagnosed from various congeners by the absence of

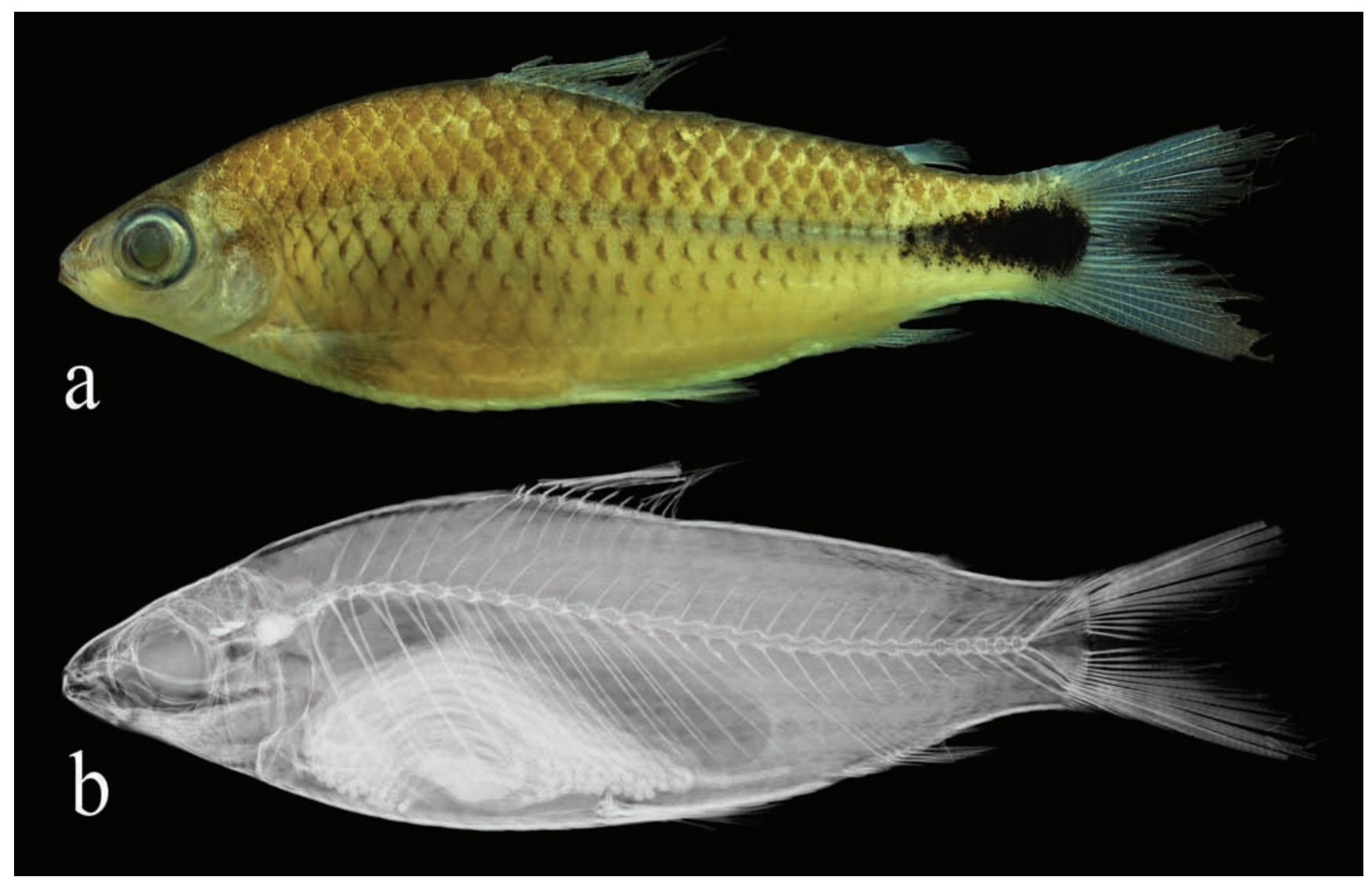

Fig. 1. Cyphocharax sanctigabrielis, holotype, MZUSP 115004, 60.7 mm SL, Igarapé Nouba Uba, rio Negro, Amazon basin, São Gabriel da Cachoeira, Amazonas State, Brazil. Views of preserved specimen (a) and radiograph (b). 
a series of dark stripes or spots running between the scale rows (vs. the presence of such dark pigmentation in $C$. helleri, C. multilineatus, and C. pantostictus), the absence of two to eight dark spots distributed along the midlateral surface of the body (vs. the presence of such pigmentation in C. biocellatus, C. punctatus, and C. vanderi), the absence of a patch of dark pigmentation on the dorsal or adipose fins (vs. the presence of such pigmentation in $C$. nigripinnis, $C$. notatus and C. vexillapinnus) and a non-fleshy upper lip (vs. lip very fleshy in C. mestomyllon). Cyphocharax sanctigabrielis can be meristically further distinguished from various other congeners by the possession of 31 pored scales along the lateral line from the supracleithrum to the hypural joint (vs. four to nine pored scales in C. aninha, $C$. saladensis and $C$. signatus, 27 in C. vanderi, 27 or 28 in C. gangamon and in sum 32 to 97 in C. abramoides, C. aspilos, C. gilbert, C. leucostictus, C. magdalenae, C. nagelii, C. nigripinnis, C. pinnilepis, C. platanus, C. santacatarinae, C. stilbolepis, and C. voga), the presence of 9 branched dorsal-fin rays (vs. 10 to 12 in C. spilotus), and the possession of 30 or 31 vertebrae (vs. 28 or 29 in C. vanderi and 32 to 37 in C. abramoides, C. aspilos, C. gilbert, C. modestus, C. nagelii, C. notatus, C. platanus, C. santacatarinae, C. stilbolepis, and C. voga). Morphometric ratios and counts serve to further discriminate C. sanctigabrielis from various congeners (for comparative data see Vari, 1992a; Vari \& Blackledge, 1996; Vari \& Chang, 2006; Vari et al., 2010, 2012).

Description. Morphometric data presented in Table 1. Body moderately elongate; elongation more pronounced in larger specimens. Dorsal profile of head convex from margin of upper lip to vertical through anterior nares, nearly straight from that point to posterior terminus of head. Dorsal profile of body slightly convex from tip of supraoccipital spine to dorsal-fin origin; straight to slightly convex and posteroventrally-slanted from base of last dorsal-fin ray to adipose-fin origin and then slightly concave to origin of anteriormost dorsal procurrent ray. Dorsal surface of body with barely apparent median ridge anterior to dorsal-fin base and transversely rounded posterior to fin base. Ventral profile of head very slightly convex to nearly straight from margin of lower lip to isthmus. Ventral profile of body smoothly convex from isthmus to pelvic-fin origin, convex from that point to rear of anal-fin base and then slightly concave to origin of anteriormost ventral procurrent ray. Prepelvic region smoothly flattened transversely, with midventral series of scales comparable in size to those on adjoining portions of body. Postpelvic region of body transversely rounded.

Dorsal fin pointed, with distal margin straight and first and second branched rays longest. Pectoral-fin profile pointed. Tip of adpressed pectoral fin falls four or five scales short of vertical through pelvic-fin origin. Pelvic fin profile pointed.
Table 1. Morphometric data for Cyphocharax sanctigabrielis $(\mathrm{N}=7)$. Range includes holotype and paratypes. $\mathrm{SD}=$ standard deviation.

\begin{tabular}{lccc}
\hline & Holotype & Range & Mean \pm SD \\
\hline $\begin{array}{l}\text { Standard length (mm) } \\
\quad \text { Percentage of standard length }\end{array}$ & 60.7 & $44.3-67.0$ & 53.1 \\
Greatest body depth & 33.2 & $30.4-33.2$ & $32.0 \pm 0.9$ \\
Snout to dorsal-fin origin & 47.9 & $46.6-48.6$ & $47.7 \pm 0.7$ \\
Snout to pectoral-fin origin & 24.6 & $24.6-27.7$ & $26.4 \pm 1.3$ \\
Snout to pelvic-fin origin & 54.3 & $52.2-54.7$ & $53.7 \pm 1.0$ \\
Snout to anal-fin origin & 80.0 & $77.6-80.0$ & $79.2 \pm 0.8$ \\
Snout to anus & 75.7 & $74.1-75.7$ & $74.6 \pm 0.6$ \\
Dorsal-fin origin to hypural joint & 57.8 & $56.4-58.9$ & $57.3 \pm 0.8$ \\
Dorsal-fin origin to anal-fin origin & 45.6 & $43.6-45.6$ & $44.7 \pm 0.7$ \\
Dorsal-fin origin to pelvic-fin origin & 33.0 & $30.9-33.0$ & $32.0 \pm 0.6$ \\
Dorsal-fin origin to pectoral-fin origin & 34.0 & $32.2-34.0$ & $33.0 \pm 0.8$ \\
Caudal-peduncle depth & 12.7 & $11.5-12.8$ & $12.4 \pm 0.4$ \\
Pectoral-fin length & 17.8 & $16.8-19.1$ & $18.0 \pm 0.8$ \\
Pelvic-fin length & 19.5 & $19.3-20.8$ & $19.9 \pm 0.6$ \\
Dorsal-fin length & 23.5 & $23.5-27.2$ & $25.3 \pm 1.4$ \\
Head length & 25.4 & $23.9-26.6$ & $25.7 \pm 0.9$ \\
$\quad$ Percentage of head length & & & \\
Snout length & 32.3 & $29.3-32.9$ & $31.7 \pm 1.3$ \\
Orbital diameter & 38.1 & $34.1-39.3$ & $36.6 \pm 1.9$ \\
Postorbital length & 34.6 & $33.1-39.0$ & $36.3 \pm 1.9$ \\
Interorbital width & 39.6 & $33.0-42.8$ & $41.0 \pm 1.2$ \\
\hline
\end{tabular}

Tip of adpressed pelvic fin falls one or two scales short of anus. Caudal fin forked with tips of lobes somewhat pointed. Adipose fin well developed. Anal fin emarginate with first branched ray longest and about three times length of ultimate ray. Tip of adpressed anal fin falls five or six scales short of point of origin of ventral most caudal-fin ray.

Head profile anteriorly pointed overall from lateral view, but rounded in region of mouth and snout. Upper jaw very slightly longer than lower jaw with mouth slightly subterminal or jaws equal. Nostrils very close; anterior circular to ovoid, posterior crescent-shaped with aperture closed by thin flap of skin separating nostrils. Adipose eyelid well developed and extending posteriorly onto anterodorsal portion of opercle. Smaller specimens with central aperture in adipose eyelid round and approximately corresponding to limits of pupil. Opening in larger individuals vertically-ovoid with eyelid overlapping anterior and posterior portions of pupil.

All scales of lateral line pored with primary laterosensory canal straight. Pored lateral-line scales from supracleithrum to hypural joint 31* (7). Pored scales on basal portions of caudal fin posterior to hypural joint $2^{*}(5)$ or 3 (2). Scales in transverse series from dorsal-fin origin to lateral line $5^{*}(6)$ or $5 \frac{1}{2}(1)$. Scales in transverse series from anal-fin origin to lateral line $4 *(3), 4 \frac{1}{2}$ (3) or 5 (1). Scales between anus and anal-fin origin $2 *(6)$ or 3 (1). Middorsal series of scales from rear of supraoccipital spine to dorsal-fin origin $9^{*}(6)$ or 10 (1). Smaller individuals lacking scales over caudal-fin lobes. Midsized and larger specimens with field of adherent scales continuing posteriorly onto basal portion of each caudal-fin lobe. Anterior scales similar in size to those on posterior portion of caudal peduncle. Adherent scales present over 
basal portions of pelvic fin; scales primarily covering last unbranched fin-ray.

Dorsal-fin rays iii, $9 *(7)$, with first unbranched ray very short. Anal-fin rays ii, $7^{*}$ (3) or iii,7 (4), with first ray very short when three unbranched rays present. Pelvic-fin rays ii, $9 *$ (7). Pectoral-fin rays 14 (1) or $15^{*}(6)$. Total vertebrae 30 (1) or $31 *(6)$.

Coloration in alcohol. Ground coloration of specimens fixed in alcohol brownish; those fixed in formalin yellowish. Overall coloration of larger specimens retaining guanine on scales silvery or silvery golden. Dusky surface coloration darker on dorsal portion of head; head dusky dorsolaterally and light colored ventrally. Chromatophores on postorbital region of head slightly larger than those on snout other than in area posterior of orbit overlapped by adipose eyelid. Overall pigmentation of that portion of postorbital region consequently somewhat lighter than that of adjoining areas.

Dusky surface coloration darker on dorsal and dorsolateral regions of body. Ground coloration of body more yellowish ventrally. Dusky surface coloration darker on dorsal and dorsolateral regions of body. Ground coloration of body more yellowish ventrally. Deep-lying, dark chromatophores forming faint, dusky midlateral stripe on body. Stripe most evident posterior of vertical through base of ultimate dorsal-fin ray and with posterior section of stripe slightly expanded vertically. Stripe continues to anterior margin of patch of dark pigmentation on midlateral surface of caudal peduncle. Middorsal region of body with series of small dark chromatophores running from tip of supraoccipital spine to anterior border of adipose fin, darker than adjoining areas. Scales on dorsal and dorsolateral regions of body with dark central regions. Light versus dark regions cumulatively forming overall reticulate pattern on those portions of body. Dark chromatophores sparsely distributed over central portion of exposed region of scales but more concentrated anteriorly. Dark pigmentation absent on scales on lateral surface of body ventral to horizontal through base of pectoral fin and also on abdomen.

Dorsal, anal, and caudal fins somewhat dusky, with ray margins outlined by small, dark chromatophores. Dark pigmentation most developed distally on caudal-fin lobes, dorsal fin, and anterior rays of anal fin. Pectoral and pelvic fins hyaline overall, but with rays outlined by small, dark chromatophores. Adipose fin speckled with small dark chromatophores.

Distribution. Cyphocharax sanctigabrielis is presently known from the upper rio Negro, Amazon basin (Fig. 2). The type locality, Igarapé Nouba Uba (Fig. 3) empties into the rio Negro upriver of the city of São Gabriel da Cachoeira.

Habitat notes. The Igarapé Nouba Uba (Fig. 3) is a shallow $(30-50 \mathrm{~cm})$, slow-flowing stream over fine and sand substrate within a well-preserved forested setting with the stream borders lined with grasses and rushes.

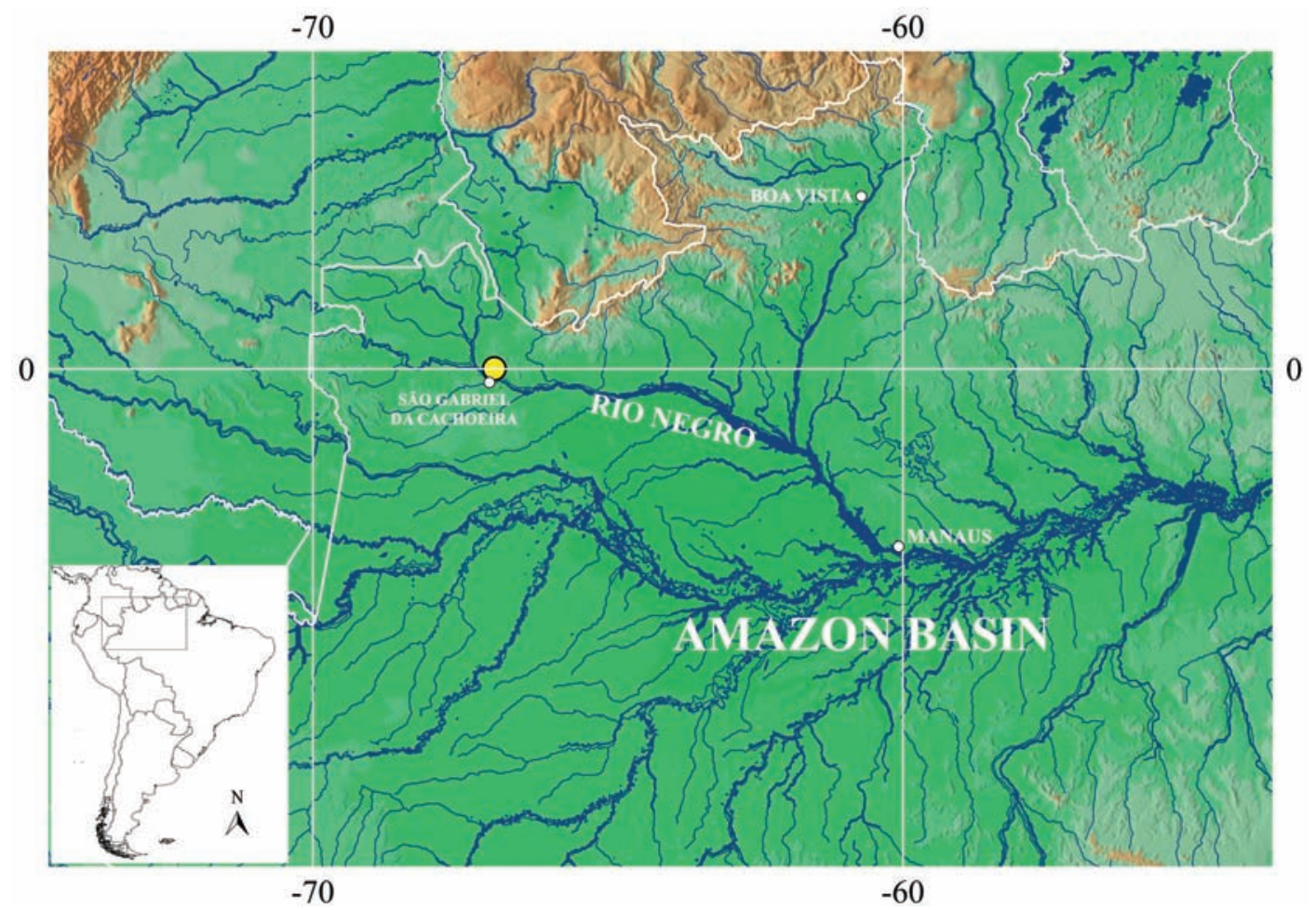

Fig. 2. Map of Western Amazon basin showing the collection locality of Cyphocharax sanctigabrielis (yellow dot) in the upper rio Negro near São Gabriel da Cachoeira, Amazonas, Brazil. 


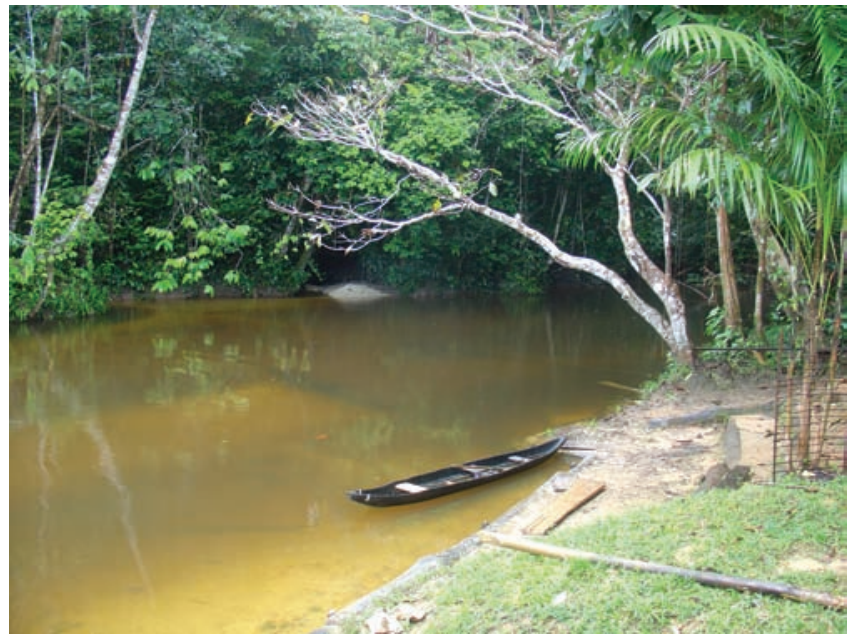

Fig. 3. Igarapé Nouba Uba, type locality of Cyphocharax sanctigabrielis, upper rio Negro, near São Gabriel da Cachoeira, Amazon basin, northern Brazil.

Etymology. The species name, sanctigabrielis, is in reference to the município de São Gabriel da Cachoeira, Amazonas State, within which the new species was discovered.

Generic placement. As presently defined, Cyphocharax is delimited by the combination of the possession of the synapomorphies for a quadritomy formed by that genus, Curimatella, Pseudocurimata and Steindachnerina in conjunction with the absence of the synapomorphies diagnostic for each of those three other genera (Vari, 1989a, 1989c, 1991, 1992a, 1992b). The absence of identified derived features common to the species of Cyphocharax leaves open the possibility that the closest relatives of Cyphocharax sanctigabrielis (and likely some other species in Cyphocharax) lie with one of Curimatella, Pseudocurimata, and Steindachnerina rather than with their nominal congeners. That possibility notwithstanding, Cyphocharax sanctigabrielis lacks the externally obvious synapomorphies present in Curimatella (Vari, 1989a: 58, 1992b: 4), Pseudocurimata (Vari, 1989c: 3) and Steindachnerina (Vari, 1989: 58; 1991: 23). In the absence of such derived features, the new species is assigned to Cyphocharax under the present definition of that genus.

\section{Discussion}

The rio Negro is the second largest tributary of the Amazon basin and is characterized by extreme black water due to high concentrations of dissolved humic and fulvic acids, the low levels of dissolved minerals, low pH (between 3.6 and 5.8) and low conductivity (Furch, 1984; Goulding et al., 1988). Goulding et al. (1988) noted that these extreme conditions possibly exclude many species and genera from that basin whereas yet others are endemic to that river system. In the case of the Curimatidae, only a subset of the species of the family known from the Amazon extend into the upper rio Negro between the rapids at São Gabriel da Cachoeira north to the río Casiquiare. These are Curimata incompta, C. ocellata, $C$. vittata, Curimatopsis macrolepis, Cyphocharax abramoides, C. multilineatus (collected in sympatry with $C$. sanctigabrielis), $C$. plumbeus, and C. spilurus (Vari, 1982, 1989b, 1992a). Of these species, only two, C. multilineatus and C. sanctigabrielis are known solely from within the rio Negro system with the latter species only known from its type locality above the rapids of São Gabriel da Cachoeira. Species from the upper portions of the río Orinoco and rio Negro which are conjoined via the río Casiquiare are presumably isolated from lower portions of their respective drainages by the Atures and Maipures rapids in the southern portions of the río Orinoco basin and the rapids at São Gabriel along the rio Negro in the northern Amazon (Lima \& Ribeiro, 2011; Lujan \& Armbruster, 2011). Albert et al. (2006) similarly hypothesized that the rapids at São Gabriel might be physical barriers blocking the dispersal of gymnotiforms from the Orinoco to Amazon lowlands. Cyphocharax sanctigabrielis is possibly yet another species endemic to the upper portions of the rio Negro above the rapids of São Gabriel da Cachoeira.

\section{Acknowledgments}

We thank Hertz F. Santos and Thiago N. Pereira (LIRP) for assistance with the radiographs. We are also grateful to Flávio A. Bockmann and Ricardo M. C. Castro (LIRP) for assistance with the radiography of the type series and to Claudio Oliveira (LBP) and Michel D. Gianeti (MZUSP) for curatorial assistance. Martin I. Taylor provided the photograph in Fig. 3 and habitat information. The authors were financially supported by the Fundação de Amparo à Pesquisa do Estado de São Paulo (Proc. 2011/08374-1 and Proc. 2013/16436-2) to BFM and the National Science Foundation (DEB-1257898) to RPV.

\section{Literature Cited}

Albert, J. S., N. R. Lovejoy \& W. G. R. Crampton. 2006. Miocene tectonism and the separation of cis- and trans-Andean river basins: Evidence from Neotropical fishes. Journal of South American Earth Sciences, 21: 14-27.

Furch, K. 1984. Water chemistry of the Amazon basin: the distribution of chemical elements among freshwaters. Pp. 167-200. Sioli, H. (Ed.). The Amazon: Limnology and Landscape Ecology. Dordrecht, Dr. H. Junk Publishers.

Goulding, M., M. L. Carvalho \& E. J. G. Ferreira. 1988. Rio Negro: rich life in the poor water. The Hague, SPB Academic Publishing.

Lima, F. C. T. \& A. C. Ribeiro. 2011. Continental-scale tectonic controls of biogeography and ecology. Pp. 145-164. Albert. J. S. \& R. E. Reis (Eds.). Historical Biogeography of Neotropical Freshwater Fishes. Berkeley and Los Angeles, University of California Press. 
Lucinda, P. H. F. \& R. P. Vari. 2009. New Steindachnerina species (Teleostei: Characiformes: Curimatidae) from the Rio Tocantins basin. Copeia, 2009: 142-147.

Lujan, N. K. \& J. W. Armbruster. 2011. The Guiana Shield. Pp. 211224. Albert. J. S. \& R. E. Reis (Eds.). Historical Biogeography of Neotropical Freshwater Fishes. Berkeley and Los Angeles, University of California Press.

Maldonado-Ocampo, J. A., R. P. Vari \& J. S. Usma. 2008. Checklist of the freshwater fishes of Colombia. Biota Colombiana, 9: 143-237.

Netto-Ferreira, A. L. \& R. P. Vari. 2011. New species of Steindachnerina (Characiformes: Curimatidae) from the Rio Tapajós, Brazil, and review of the genus in the Rio Tapajós and Rio Xingu basins. Copeia, 2011: 523-529.

Pavanelli, C. S. \& H. A. Britski. 1999. Description of a new species of Steindachnerina (Teleostei: Characiformes: Curimatidae) from the upper Rio Paraná basin, Brazil. Ichthyological Exploration of Freshwaters, 10: 211-216.

Vari, R. P. 1982. Systematics of the Neotropical characoid genus Curimatopsis (Pisces: Characoidei). Smithsonian Contributions to Zoology, 373: 1-28.

Vari, R. P. 1989a. A phylogenetic study of the Neotropical characiform family Curimatidae (Pisces: Ostariophysi). Smithsonian Contributions to Zoology, 471: 1-71.

Vari, R. P. 1989b. Systematics of the Neotropical characiform genus Curimata Bosc (Pisces: Characiformes). Smithsonian Contributions to Zoology, 474: 1-63.

Vari, R. P. 1989c. Systematics of the Neotropical characiform genus Pseudocurimata Fernández-Yépez (Pisces, Ostariophysi). Smithsonian Contributions to Zoology, 490: 1-28.

Vari, R. P. 1991. Systematics of the Neotropical characiform genus Steindachnerina Fowler (Pisces, Ostariophysi). Smithsonian Contributions to Zoology, 507: 1-118.
Vari, R. P. 1992a. Systematics of the Neotropical characiform genus Cyphocharax Fowler (Pisces, Ostariophysi). Smithsonian Contributions to Zoology, 529: 1-137.

Vari, R. P. 1992b. Systematics of the Neotropical characiform genus Curimatella Eigenmann and Eigenmann (Pisces, Ostariophysi), with summary comments on the Curimatidae. Smithsonian Contributions to Zoology, 533: 1-48.

Vari, R. P. 2003. Family Curimatidae. Pp. 51-64. In: Reis, R. E., S. O. Kullander \& C. J. Ferraris Jr. (Eds.). Check list of the freshwater fishes of South and Central America. Porto Alegre, Edipucrs.

Vari, R. P. \& T. A. Blackledge. 1996. New curimatid, Cyphocharax laticlavius (Ostariophysi: Characiformes), from Amazonian Ecuador, with a major range extension for C. gouldingi. Copeia, 1996: 109-113.

Vari, R. P. \& F. Chang. 2006. Cyphocharax derhami, a new species (Ostariophysi: Characiformes: Curimatidae) from northeastern Peru. Ichthyological Exploration of Freshwaters, 17: 93-96.

Vari, R. P., B. L. Sidlauskas \& P. Y. Le Bail. 2012. New species of Cyphocharax (Ostariophysi: Characiformes: Curimatidae) from Suriname and French Guiana and a discussion of curimatid diversity on the Guiana Shield. Cybium, 36: 63-69.

Vari, R. P., A. M. Zanata \& P. Camelier. 2010. New species of Cyphocharax (Ostariophysi: Characiformes: Curimatidae) from the Rio de Contas Drainage, Bahia, Brazil. Copeia, 2010: 382-387.

Wosiacki, W. B. \& D. P. S. Miranda. 2013. Description of a new small species of the genus Cyphocharax (Characiformes: Curimatidae) from the lower Amazon basin. Copeia, 2013: 627-633.

Submitted September 12, 2013 Accepted December 3, 2013 by Francisco Langeani Published June 30, 2014 